\title{
DisPUTING NATIONAL HistoRies: Some Recent Australian Debates
}

\author{
Transforming Cultures eJ ournal, \\ Vol. 1 No 1, March 2006 \\ http:// epress.lib.uts.edu.au/journals/TfC
}

\section{Disputed National Histories}

\section{Ann Curthoys}

National history seems to be a form of history marked by a particularly strong relation between past and present. In the last few decades, the most serious historiographical conflicts, and the ones which have attracted public as well as scholarly attention, have tended to be those where national honour was felt to be at stake. Very often they have concerned either the foundation of the nation, or the national role in war, and sometimes both; think of the example of Japan, Israel, the United States, and Australia, to name just a few. These debates have attracted particular heat because history was seen to have implications not only for specialist historians but also for the morality and future of the nation.

History's national significance has arisen from and in turn strengthened the national framework for historical scholarship since at least the early nineteenth century. Perhaps the triumph of national over imperial and other transnational histories was strongest in the last four decades of the twentieth century, when, in the context of decolonisation in Africa and Asia, and the loosening of ties between Britain and its former Dominions as the former looked towards Europe and the latter engaged with new geopolitical realities, what had once been imperial histories became decidedly national. The break up of empire, that is to say, involved the fragmentation and separation of imperial historiography as each post-colonial nation gradually developed its own professional, academic, national history. ${ }^{1}$ In turn, these national histories became closely entwined with national identity and politics, and thus liable to witness internal dispute, and in some cases, such as Israel, external conflict as well.

\footnotetext{
${ }^{1}$ Hopkins, A.G. (1999) "Back to the Future: From National History to Imperial History”, Past and Present, 164:198 - 243.
} 
This sequence of historiographical development and disputation has been clearly evident in Australia also. Australian histories written before World War II had emphasised Australia's place within the British Empire and had erased or minimized the history of colonization of indigenous peoples, putting in its place a story of settler and pioneer hardships. In some versions the story of settler hardship was a radical nationalist legend celebrating the itinerant male workers of the bush and the outback; in others it was a largely classless pioneer legend that celebrated those who had subdued the land for pastoralism and agriculture - small and large farmers, men and women alike. Australia's pioneering settlers were remembered as having endured the harshest continent on earth, with its endless drought, fire, and flood, their struggle most poignantly signified by the near starvation in the first years of settlement, or in the story of the selectors later in the century who attempted to carve out a living from an often unforgiving land.

Both versions of this pioneer national narrative were silent on race and ethnicity, referring only infrequently to non-British immigrants, and obscuring the dispossession of indigenous peoples almost entirely. In both, the hardships endured by white people, especially those of British or Irish origin, were at the heart of the narrative. In common with other colonial and settler societies, settler Australians developed narratives of reversal, placing indigenous people as the invaders and seeing the settlers as the defenders of their land. Like so many others, from the United States to Canada to Israel and elsewhere, settler Australians have tended to see themselves as victims, not oppressors. This reversal was noted as long ago as 1845, when visiting Polish Count Strzelecki observed that the indigenous people of Tasmania had been seen "as a sort of brute intruder" on lands that rightly belonged to the settlers. ${ }^{2}$ They have seen themselves as the rightful owners of the land in contrast to indigenous peoples, perceived as nomads, whose hold upon it is tenuous and undeserved. In 1997, a contemporary indigenous leader, Galarrwuy Yunupingu, pointed to the irony of a situation in which Aboriginal people who stay on their own land as far as they are permitted, to protect it, become in white Australian mythology the wanderers, the nomads, on 'walkabout', while those inveterate wanderers, the European immigrants

\footnotetext{
${ }^{2}$ Stzelecki, Paul Edmund (nd) Physical description of New South Wales and Van Diemen's Land. London: Longman, Brown, Green and Longmans: 348.
} 
who have crossed oceans and strayed far from their homelands and who continue restlessly to roam and wander within the continent, are named the settlers, those who stay at home. ${ }^{3}$ A similar point has been made more recently by Hugh Brody, in his book The Other Side of Eden: Hunters, Farmers, and the Shaping of the World; agricultural peoples, he points out, are the wanderers, while hunting and gathering peoples, like the Inuit, generally stay within their own territories. ${ }^{4}$

Throughout the former British Empire, these older settler narratives came under challenge after the Empire dissolved in the 1960s. The idea that the settlers not the indigenous peoples had been the invaders gradually came to the fore, though this was not an easy process. For some decades, from the 1950s to the 1970s, the historians' focus on the nation, and indeed their nationalism as custodians of national identity, made it difficult for most of them to think beyond the framework developed by a white nationalistic settler consciousness. It was only when public concern with racism in its local and international manifestations increased rapidly from the late 1960s that professional historians finally moved to the forefront in the investigation of histories of Indigenous colonisation, dispossession, and institutionalisation. ${ }^{5}$ Historians such as Charles Rowley, Henry Reynolds, Lyndall Ryan, Ray Evans, Andrew Markus, Kay Saunders, Heather Goodall, Ann McGrath, and many others began to write histories which took indigenous colonisation as their focus, and which were highly critical of settler actions and often imperial governments as well. In adopting this critical approach these historians shared similar concerns with their counterparts in other former colonies of settlement, in Canada and New Zealand especially. From the 1980s and 1990s these new histories influenced school and university curricula, and popular histories in film, television, and newspapers. The national narrative changed: a narrative of land seizure, bitter frontier conflict, dispossession, subsequent economic exploitation and social control replaced earlier ideas of a scattered indigenous population that had mysteriously faded away as white settlers approached. Very slowly, all migrants and their descendants, including those of non-Anglo-Celtic background, came to be recognised as

\footnotetext{
${ }^{3}$ Galarrwuy Yunupingu (13 February 1997) Speech to National Press Club.

${ }^{4}$ Brody, Hugh (2002) The Other Side of Eden: Hunter-Gatherers, Farmers, and the Shaping of the World. London: Faber and Faber: 7.

${ }^{5}$ Landmarks in this development included Charles Rowley's, (1970) The Destruction of Aboriginal Society Harmondsworth: Penguin, the journal Aboriginal History (founded in 1977), Richard Broome’s (1982) Aboriginal Australians Sydney: George Allen and Unwin, and Henry Reynolds’ widely-read series of books beginning with (1981) The Other Side of the Frontier. Harmondsworth: Penguin.
} 
colonisers, as part of and benefiting from colonisation with its history of indigenous dispossession. $^{6}$

Yet these histories met bedrock resistance in non-indigenous Australian popular consciousness, a resistance that became much clearer with the rise of Pauline Hanson's One Nation, and the election of the Howard government in 1996. I have argued elsewhere that one reason many non-Indigenous Australians could not accept the new histories was that they remained committed to the story of their own sufferings, and had difficulty in seeing themselves as the beneficiaries of the colonisation process. ${ }^{7} \mathrm{~A}$ reaction to critical histories of colonisation began to emerge, spear-headed by historian Geoffrey Blainey and indeed by Prime Minister John Howard himself. The History Wars of the early 2000s took this reaction a good deal further. The desire for a national history that placed non-indigenous Australians and their forebears in a more heroic light, and at the centre of that history, found expression especially in the work of Keith Windschuttle, who cast the settlers as good civilised Europeans and the indigenous peoples as primitive people with no sense that the land was theirs, and at worst, idle savages and murderers. ${ }^{8}$

\section{The Genocide Debate}

The History Wars became entangled with another debate which had begun a few years before, over whether the dispossession and large scale loss of life of indigenous peoples in the course of settlement could accurate be described as genocide. The genocide debate had begun with the Human Rights Commission's Bringing Them Home report in 1997 into the removal of Indigenous children, past and present. When the report pointed out that the taking of children with the intent of destroying a group was, according to the UN Convention on Genocide, a form of genocide, many Australians were horrified and resistant. The debate soon widened to include consideration of whether the huge loss of Indigenous life in the wake of settlement could also be considered a case of genocide. In his book, An Indelible Stain? The question of genocide in Australia's

\footnotetext{
${ }^{6}$ See Ann Curthoys (2000) “An Uneasy Conversation: the Indigenous and the Multicultural”, in John Docker and Gerhard Fischer, (eds.) Race Colour and Identity in Australia and New Zealand. Sydney: UNSW Press, 2000; and Ghassan Hage (2002) Against Paranoid Nationalism: Searching for Hope in a Shrinking Society, Sydney: Pluto Press.

${ }^{7}$ Ann Curthoys (1999) "Whose Home? Expulsion, Exodus, and Exile in White Australian Historical Mythology”, Journal of Australian Studies 61:1-18. A shorter version is in Bain Attwood and Stephen Foster, eds, Frontier Conflict, Canberra: National Museum of Australia, 2003.

${ }^{8}$ Keith Windschuttle (2002) The Fabrication of Aboriginal History, Volume one. Sydney: Macleay Press.
} 
history (2001), Henry Reynolds considered the question in some detail. Using the UN definition of genocide, he concluded that there were "genocidal moments", notably on the Queensland frontier, when settlers entered into a genocidal frenzy setting out to destroy all indigenous people in the area chosen for settlement. One cannot, however, he argued, apply the term where it is most often used, in relation to Tasmania. The British authorities in Tasmania, he argues, at no point wished to destroy the Aboriginal people; what they wanted was the land and they sought to protect the Aboriginal Tasmanians as best they could. That they were unable to realize this desire to protect was a product of historical circumstances, not of any intent on their part to destroy a whole people. Without intent, he argued, the concept of genocide cannot apply. ${ }^{9}$

A little later, Keith Windschuttle entered into the genocide debate, arguing that Australian critical historians had wrongly applied the notion of genocide to Tasmanian and indeed Australian Aboriginal history generally. ${ }^{10}$ In fact, none of the expert historians Windschuttle considers, especially Henry Reynolds and Lyndall Ryan, had used the word genocide to describe what had happened on the Tasmanian frontier. Although Indigenous Australians have wanted to apply the term 'genocide' to their own experience and history and to make genocide a crime in Australian law, most nonIndigenous Australians, including the critical historians, have been very wary of the term. Reynolds and Ryan and others preferred to stress other matters - the strength of Aboriginal resistance (Reynolds), or the importance of acknowledging the fact of Aboriginal survival (Ryan). In combination with the emerging Indigenous political movement in Tasmania in the 1970s and 1980s, Ryan's work helped to alert a public used to the idea that Tasmanian Aborigines had disappeared from the face of the earth that there were indeed survivors and descendants who had legitimate political claims to land and other rights. Also joining the genocide debate was Bain Attwood, who responded to Windschuttle by pointing out that he had misrepresented historians such as Henry Reynolds and Lyndall Ryan, and agreeing with Windschuttle that the term was inappropriate to Australian history. ${ }^{11}$

\footnotetext{
${ }^{9}$ Henry Reynolds (2001) An Indelible Stain? The question of genocide in Australia's history, Melbourne: Viking.

10 The arguments concerning genocide appeared earlier in (2001) “The Fabrication of Aboriginal History”, New Criterion 20(1) <http://www.newcriterion.com/archive/20/sept01/keith.htm>, and were repeated in The Fabrication of Aboriginal History.

${ }^{11}$ For a more detailed discussion of these issues see my (forthcoming) "The Killing of History and the History of Killing”, in Antoinette Burton, ed., Archive Stories. London: Routledge.
} 
There is, however, another possible response. This is that the term genocide is in fact applicable to Australian history. In this argument, Windschuttle, Reynolds, and Attwood can all be seen as having defined the term too narrowly. I want to present the case here for seeing genocide as a helpful concept in Australian history, as long as we define it carefully and especially address the vexed question of intent with historical knowledge and conceptual care.

The word 'genocide' was coined in 1944 by the eminent Polish Jewish jurist, Raphael Lemkin, in his remarkable text, Axis Rule in Occupied Europe. Initially concerned by the rise of Nazism in Germany, and later by its policies and practices of exterminating the Jews and replacing them and other people in Eastern Europe with German settlers, Lemkin argued that international law could be developed and invoked to prevent a recurrence of attempts to destroy whole peoples. In the course of developing such law, a new word was needed to describe these crimes, 'genocide', literally the killing of a people. After much lobbying Lemkin eventually succeeded in having the United Nations pass in December 1948 a Convention on the Prevention and Punishment of the Crime of Genocide. The convention defined genocide as attempting to destroy, in whole or in part, a national, ethnical, racial or religious group, through killing or seriously harming its members, undermining its conditions of life, preventing births within the group, or forcibly transferring children to another group. ${ }^{12}$

Lemkin's aims were not only to establish a new crime, and mechanisms for its prevention, but also to reinterpret the course of human history in light of his new concept. Where some identify the idea of genocide with the Holocaust, Lemkin, its creator, went in quite the opposite direction. For him, the experience of the Holocaust should lead us to develop an understanding of genocide more broadly, as a pattern throughout human history, in which episodes of mass killing, or other forms of attempts to destroy a whole people, recur from time to time. He hoped that his notion of 'genocide' could be used not only to develop international legal systems to help prevent its recurrence, but also to interpret past episodes of mass destruction of peoples through killing, land seizure, the importation of diseases, prevention of births, stealing of

\footnotetext{
${ }^{12}$ See Ann Curthoys and John Docker,(2000) “Introduction: Genocide: Definitions, Questions, Settler Colonies", Aboriginal History, 25: 1-15.
} 
children and in other ways removing the very foundations of life of a human group. Thus the modern concept of 'genocide' originated with, and takes much of its modern relevance from, the example of the Holocaust, the outstanding modern case of the attempted destruction of a whole people. Yet it is also, from the beginning, a way of characterising long term historical processes, which could include colonisation, the destruction of a society and people and its attempted replacement by another society and people.

In the second half of the 1940s, Lemkin set out to write a two or three volume history of genocide. He developed a typology or framework for looking at a range of historical cases, and then studied about forty cases in turn. He went back to ancient history, to Carthage, and ended with twentieth century cases such as the Armenian genocide and the Holocaust. He worked on the history in the late forties and early fifties, writing chapters at the same time as he was working tirelessly, and in the end successfully, to have the UN pass the Genocide Act. The Lemkin papers in the American Jewish Historical Society library in New York, and also in the New York City Library, include notes, plans, and draft chapters for an intended two or three-volume study of the history of genocide, and in particular they include a draft chapter on Tasmania. (There are also indications that he also drafted a more general chapter on Australia, but this chapter is not in these archives and may no longer exist.) Lemkin never published his book on the history of genocide, dying in 1959 before it could be completed.

In this draft chapter, which has since been published in Patterns of Prejudice (2005), Lemkin applies his notion of genocide to Tasmania, using his own newly-developed method for assessing historical events as possible examples of genocide. This method meant investigating the historical background, the conditions leading to it, the methods and techniques used (whether massacre or deprivation of the foundations of life), the intent and motivation of the genocidists, the opposition to genocide within the genocidist group, the role of propaganda, the responses of the victim group and also of outside groups, and the aftermath and consequences. Using this framework, and relying largely on James Bonwick's The Last of the Tasmanians (1870), supplemented by other later works, Lemkin developed his own account of what happened in Tasmania. He asked, in a subheading, "Intent to Destroy - who is guilty - Government or Individuals?”, and placed the blame for the destruction of Tasmanian society first on 
settlers and convicts who attacked the Aboriginal people, and second on the British authorities who confined them to Flinders Island, killing them, he says, with "misguided kindness". He sees the brutal treatment, kidnapping, prostitution and economic exploitation of the women as a form of genocide in that it eventually destroyed Tasmanian Aborigines' ability to reproduce. Lemkin had a particular interest in the stealing of children as a form of attempting to destroy a human group, and saw this as especially evident in the Tasmanian case. He viewed the governing authorities not as planning or coordinating genocide, but as failing in their basic duty of protection. ${ }^{13}$

Lemkin's wide-ranging definition of genocide was to be narrowed over the subsequent decades; most genocide scholarship saw genocide as state-organised mass murder, on the model of the Holocaust. In the last five years, however, partly as a result of reexamining Lemkin's own writing on the subject, the term has generally broadened to include cases which are not state-directed, and also historical cases where the destruction of a people occurred less through mass murder than through other means deprivation of sources of food, removal of women and children, prevention of births, and in general undermining the foundations of life of a people. This new scholarship has taken up Lemkin's stress on the connections in European history between genocide and colonisation, and especially the history of Nazi colonisation in the vast landmass east of Germany. ${ }^{14}$

Modern genocide scholars have also taken up and reconsidered the question of intent. This has long been a difficult issue for genocide scholarship (and indeed for international courts); it is often difficult to prove intent in a case of mass killing or expulsion when many different people and motivations are involved. Tony Barta, an Australian expert in German history with a good general knowledge of Australian colonial history, in the mid 1980s had already probed the question of genocide and intent that Reynolds was later to raise, coming to the opposite conclusion. Barta drew attention to that key section of Lemkin for any discussion of colonialism, where he says that genocide proceeds in two phases: "destruction of the national pattern of the

\footnotetext{
${ }^{13}$ See Ann Curthoys (2005) “Raphaël Lemkin’s ‘Tasmania’: an introduction” Patterns of Prejudice, 39(2): 162-69.

${ }^{14}$ See Dirk Moses, ed.(2005) Genocide and Settler Societies: Frontier Violence and Stolen Indigenous Children in Australian Society. New York: Berghahn Books and his forthcoming collection, Genocide and Colonialism, New York, Berghahn Books.
} 
oppressed group" followed by "the imposition of the national pattern of the oppressor". ${ }^{15}$ Such a definition clearly applied to the Australian case: as he said, "there is no dispute that the basic fact of Australian history is the appropriation of the continent by an invading people and the dispossession, with ruthless destructiveness, of another”. There can also be no doubt, he says, "about the disintegration of Aboriginal society, traditional culture, and religion, the destruction of the Aborigines' economic existence, their languages, their personal security, liberty, health, and dignity”. The process and the effect were clearly genocidal. The intent was less direct, being to take the land rather than destroy the people. It was only when Aborigines resisted the loss of their conditions of life that they were met with a determined settler and government response.

This seems to me a crucial point. If we look for instances of attempts to destroy a people, and especially of moments when this desire was clearly articulated, we will find, as Reynolds has done, limited instances of genocidal intent. But if we consider the question of intent indirectly, that is, that the intent was to take the land no matter what the consequences for indigenous people, then we can see a general pattern within colonisation of a degree of carelessness about the future of entire peoples that was so extreme it amounts to genocide. If we also consider that the consequences of land were not at all unpredictable or surprising - in the Australian case they were either known or predictable from experience in North America and the Caribbean - then the continued land seizure can be seen as a genocidal project. Perhaps some colonising decisions were made without this knowledge, but as time went on colonisers knew the likely consequences of their actions. As Roger Smith writes, of colonisers in general:

Sometimes ... genocidal consequences precede any conscious decision to destroy innocent groups to satisfy one's aims. This is most often the case in the early phase of colonial domination, where through violence, disease, and relentless pressure indigenous peoples are pushed towards extinction. With the recognition of the consequences of one's acts, however, the issue is changed: to persist is to intend the death of a people. This pattern of pressure, recognition, and persistence is typically what happened in the nineteenth century. ${ }^{16}$

\footnotetext{
${ }^{15}$ Tony Barta (1984) “After the Holocaust: Consciousness of Genocide in Australia”, Australian Journal of Politics and History, 31(1): 154-61, p.154.

${ }^{16}$ Roger W. Smith (1987) "Human Destructiveness and Politics: The Twentieth Century as an Age of Genocide”, in I. Wallimann and M.N. Dobkowski (eds.) Genocide and the Modern Age New York, 1987, p. 23. Quoted in Dirk Moses (2005: 28).
} 


\section{National, Imperial and Transnational Histories}

These debates over settler history, indigenous history, frontier violence, and genocide and colonialism have been conducted largely within a national framework. Yet they have, of course, an imperial dimension as well. Clearly, despite moments of angst within British ruling elites in the 1830s in particular, the colonisation of Australia, with its dire consequences for Aboriginal people, was a British project. The events at issue in the Tasmanian case, and we could consider many others, occurred before there was an Australian nation as such; they happened in the context of a British colonial empire with a number of Australian colonies. And yet of course, it was also, if we read back from the present to the past, an Australian project. It was through dispossession and displacement that white Australian colonies and then the Australian nation were created. Given that the claims of indigenous Australians have a strong historical component, so too does the reaction to those claims. In this way current politics and historical understandings are intimately bound together.

The mood in historiography, however, has become very transnational, a trend that can sometimes work against the political relevance of history, and at other times enhance it. Historians everywhere are seeking to escape the national straitjacket of their work, extend their analyses, and appeal to wider audiences, but in the process face the danger of losing the national audiences they once had. This transnational desire has some particular implications for these bitter national historical disputes. One effect will be to recognise more clearly the debates of others, and to see the similarities and differences between them. While the debates over the founding of Israel in which Ilan Pappé has been deeply involved are different in many respects from the Australian debates I've been discussing here, there are also some similarities, especially in the ways in which the critical historians have been seen as betrayers of their own country. Some of the techniques of argument are very similar, even down to the title of key texts; Keith Windschuttle's The Fabrication of Aboriginal History (2002) clearly echoes Efraim Karsh's book, Fabricating Israel History (1997), as it does similar books produced in the course of Japanese debates over the Nanjing Massacre of 1937 and the events of World War II. ${ }^{17}$ It helps, I think, to put our own conflicts in international perspective. A second effect of a more transnational approach will be to engage with historians who

\footnotetext{
${ }^{17}$ Efraim Karsh (2000) Fabricating Israeli History: the 'new historians'. London: Frank Cass. First published 1997.
} 
see Australian history very differently from the way Australian historians do. Just as the engagements between Israeli and Palestinian historians, and between Japanese and Chinese historians will affect the debates, so engagement between non-Indigenous and Indigenous peoples within Australia and with other settler and imperial historiographies outside it has and will continue to shift Australian historiographical debate.

\section{Finally, what is history anyway?}

In his paper, "Building on Sand”, Pappe tells us that one of the most challenging tasks in the Israeli debates has been not just providing a different historical narrative to the prevailing one, but in connecting the historical discussion to a more epistemological understanding of "what is history and how history is received by the public at large". He describes how in an historiographical conflict historians on both sides will be impatient with any suggestion of relativism (what he calls "soft relativism”): each side believes it is correct and that it can be shown to be so. And he argues that historians need to take time to explain to the public that sometimes what happened is not very clear, and that historical investigation is part of an ongoing process, in which historians are connected both to present conflicts and also to past ones, in a complex way.

In Australia, too, the debates over frontier violence have led to some interesting reconsideration of a range of epistemological and ethical issues. Some of the questions that have arisen in public debate are: Is it possible to have more than one true account? How do historians develop accurate historical accounts when the evidence is fragmentary? How do we view histories that show no empathy with people's sufferings in the past? Can one have too much empathy for such sufferings? If one detail in a given historical account is found to be incorrect, what implications does this have for a historian's overall narrative and interpretation? How do we distinguish between interpretation, error, ideologically driven history, and fabrication? These debates are of course unresolved, but public interest in them has been heightened and new work is emerging on questions of history and truth. ${ }^{18}$ It will be interesting and important to see how the debates unfold.

\footnotetext{
${ }^{18}$ See, for example, Stuart Macintyre \& Anna Clark (2003) The History Wars. Melbourne University Press; Stuart Macintyre (ed.) (2004) The historian's conscience: Australian historians on the ethics of history. Melbourne University Press; Ann Curthoys \& John Docker (2005) Is History Fiction? UNSW Press and University of Michigan Press; Bain Attwood (2005) Telling the Truth about Aboriginal History Sydney: Allen and Unwin.
} 


\section{References}

Attwood, B. (2005) Telling the Truth about Aboriginal History. Sydney: Allen and Unwin.

Attwood, B. \& Foster, S. (eds.) (2003) Frontier Conflict. Canberra: National Museum of Australia.

Barta, T. (1984) “After the Holocaust: Consciousness of Genocide in Australia”, Australian Journal of Politics and History, 31 (1): 154-61.

Brody, H. (2002) The Other Side of Eden: Hunter-Gatherers, Farmers, and the Shaping of the World. London: Faber and Faber.

Broome, R. (1982) Aboriginal Australians London: George Allen and Unwin.

Curthoys, A. (1999) "Whose Home? Expulsion, Exodus, and Exile in White Australian Historical Mythology” Journal of Australian Studies 61:1-18.

-- (2000) “An Uneasy Conversation: the Indigenous and the Multicultural” in Docker, J. and Fischer, G. (eds.) Race Colour and Identity in Australia and New Zealand. Sydney: UNSW Press 2000.

-- (2005) “Raphaël Lemkin’s ‘Tasmania’: an introduction” Patterns of Prejudice, 39(2): 162-69.

-- (forthcoming) “The Killing of History and the History of Killing” in Antoinette Burton (ed.) Archive Stories. London: Routledge.

Curthoys, A. \& Docker, J. (2000) “Introduction: Genocide: Definitions, Questions, Settler Colonies”, Aboriginal History, 25: 1-15.

-- (2005) Is History Fiction? UNSW Press and University of Michigan Press.

Efraim Karsh, E. (2000) Fabricating Israeli History: the "new historians" (2nd Edition). London: Frank Cass.

Hage, G. (2002) Against Paranoid Nationalism: Searching for Hope in a Shrinking Society. Sydney: Pluto Press.

Hopkins, A.G. (1999) "Back to the Future: From National History to Imperial History”, Past and Present, 164:198 - 243.

Efraim Karsh, (2000) Fabricating Israeli History: the 'new historians'. London: Frank Cass.

Macintyre, S. (ed.) (2004) The historian's conscience: Australian historians on the ethics of history. Melbourne University Press

Macintyre, S \& Clark, A. (2003) The History Wars. Melbourne University Press.

Moses, D.(ed.) (2005) Genocide and Settler Societies: Frontier Violence and Stolen Indigenous Children in Australian Society. New York: Berghahn Books.

-- (2005) (forthcoming) Genocide and Colonialism. New York: Berghahn Books.

Reynolds, H. (1981) The Other Side of the Frontier. Harmondsworth: Penguin -- (2001) An Indelible Stain? The question of genocide in Australia's history. Melbourne: Viking.

Rowley, C. (1970) The Destruction of Aboriginal Society Harmondsworth: Penguin. 
Smith, R.W. (1987) "Human Destructiveness and Politics: The Twentieth Century as an Age of Genocide” in I. Wallimann, I. \& Dobkowski M.N. (eds.) Genocide and the Modern Age. New York:

Stzelecki, P.E. (nd) Physical description of New South Wales and Van Diemen's Land, London, Longman, Brown, Green and Longmans.

Windschuttle, K. (2001) “The Fabrication of Aboriginal History”, New Criterion 20(1) http://www.newcriterion.com/archive/20/sept01/keith.htm -- (2002) The Fabrication of Aboriginal History, volume one. Sydney: Macleay Press.

Yunupingu, G. Speech to National Press Club, 13 February 1997. 